\title{
The Development and Registration of "Bate", Oat (Avena sative L.) Variety for Western Oromia, Ethiopia
}

\author{
*Mekonnen Diribsa Abuye Tulu Waqgari Keba \\ Gutu Fekeda Warku Temesgen \\ Oromia Agricultural Research Institute, Bako Agricultural Research Center, \\ PO Box 03, Bako, Oromia, Ethiopia
}

\begin{abstract}
Eight Oat (Avena sativa L.) genotypes including standard check were essentially evaluated for their herbage dry matter yields, grain yields and nutritional quality characters at two environments (Bako and Billo) Western Oromia during 2014, 2015 and 2016 main cropping season with the objective of selecting the top performing oat (Avena sativa L.) genotypes for variety development. The tested genotypes were ILRI 6710, ILRI 5453, ILRI 5518, ILRI 6207, ILRI 712, ILRI 8237, Jasari (local check) and Bonsa (standard check). The genotypes were arranged in randomized complete block design with three replications. Data on herbage DM yield, grain yield and other agronomic traits were collected and analyzed using GenStat software. The combined analysis for herbage dry matter yield indicated that a significant differences $(\mathrm{p} \leq 0.01)$ were observed among genotypes, which ranged from 7.36-9.03 ton $\mathrm{ha}^{-1}$. Bate variety had produced mean herbage DM yield of 8.56 ton ha ${ }^{-1}$ with $12.93 \%$ ton $\mathrm{ha}^{-1}$ yield advantage over the standard check (Bonsa) which produced 7.58 ton ha ${ }^{-1}$ Similarly, grain yields differed significantly $(\mathrm{p} \leq 0.01)$ among the genotypes, which ranged from 28.79 to $31.99 \mathrm{qt} \mathrm{ha}^{-1}$ with a mean of $30.49 \mathrm{qt} \mathrm{ha}^{-1}$. Accession ILRI 5518 gave the highest mean grain yields (33.67 qt ha $\mathrm{q}^{-1}$ ) followed by Bate variety (31.99 $\mathrm{qt} \mathrm{ha}^{-1}$ ) while Jasari variety gave the lowest (28.79 $\mathrm{qt} \mathrm{ha}^{-1}$ ) over locations. Besides, significant results $(\mathrm{p} \leq 0.01)$ were observed in nutritive values for DM, IVOMD and OM among the tested genotypes while nonsignificant $(\mathrm{p}>0.05)$ results were observed in crude protein and fiber quality parameters (NDF, ADF and lignin). Genotype and genotype by environment interaction biplot analysis (GGE) also confirmed that Bate variety showed better stability and thus ideal variety recommended for production in the tested environments and other areas with similar agro-ecologies.
\end{abstract}

Keywords: Avena sativa L., Bate, Genotype, Herbage yield, Quality parameters

DOI: $10.7176 /$ ALST/83-02

Publication date: November $30^{\text {th }} 2020$

\section{Introduction}

The success and prosperity of livestock farming is determined by adequate and timely availability of feed. The green forages are major and the most economical source to fulfill the dietary needs of livestock. The insufficient fodder supply is characterized as major constrain of low animal performance for milk and meat production (Rana et al., 2014, Ahmad et al., 2014). On the other hand, the continuous and long term feeding with poor quality forage results in malnutrition in animals. Livestock feed resources in Ethiopia are mainly obtained from natural and improved pastures, crop residues, forage crops, agro-industrial by-products and non-conventional feeds (CSA 2012). The contribution of these feed resources, however, depends up on the agro-ecology, the type of crop produced, accessibility and production system (Ahmed et al., 2010). Though, natural pasture is the major source of livestock feed in Ethiopia, its importance is gradually declining because of the expansion of crop production into grazing lands, redistribution of common lands to the landless and land degradation (Berhanu et al., 2009). This and other feed resources related problems became initiating forces for the need of improved forage germplasm introduction and evaluation (like Avana sativa). Oat (Avena sativa L.) is a cereal forage crop which belongs to poaceae family. It is used mostly for animal feeding and to some extent as human food. The use of oat as animal feed has declined steadily owing to emerging use and interest in oats as human health food (Ahmad et al., 2010). It is favorite feed of animals and its straw is soft and superior to wheat and barley. The oat grain is valuable feed for almost all categories of animals (Zaman et al., 2006). The oat is fast growing and produces a significant amount of fresh fodder within short period (60 to 70 days) with adequate nutritional facts. It contains large amount of digestible crude protein, total digestible nutrients (TDN), vitamin B1, minerals and fat. Thus far, one hundred three (103) Avena sativa genotypes were introduced and evaluated at Bako Agricultural Research Center resulting in release of one oat variety with high performance against standard check across tested environments. Therefore, the objective of the study was to select the top performing oat varieties for variety release.

\section{Materials and Methods}

Eight genotypes of oats (Avena sativa L.) including two standard checks (Bonsa and Jasari) and one adopted variety (Jasari) were tested across locations (Bako and Billo) for three cropping season (2014-2016 G.C). The 
objective of the experiment was to evaluate the performance of Avena sativa genotypes for herbage DM yield and other agronomic parameters and their stability across environments. The tested accessions were ILRI 6710; ILRI 5453, ILRI 5518, ILRI 6207, ILRI 712, ILRI 8237, Jasari and Bonsa as standard check. The genotypes were arranged in randomized complete block design with three replications in which each plot comprises of six rows having $1.8 \times 2.0 \mathrm{~m}$ length. Seeds were planted in rows spaced $30 \mathrm{~cm}$ apart. A $100 \mathrm{~kg} \mathrm{ha}^{-1}$ DAP and $100 \mathrm{~kg}$ of urea fertilizer were applied in which split application urea was followed for urea. Recommended agronomic package of practices were followed to raise a healthy crop. Data from herbage yield, seed yield and other important agronomic parameters and forage quality parameters were measured as dependent variables. For forage sampling $200 \mathrm{~g}$ fresh biomass were taken and dried in an oven at $65^{\circ} \mathrm{c}$ for 72 hours to a constant weight. Partially dried feed samples were ground to pass through a $1 \mathrm{~mm}$ sieve screen using Wiley mill and stored in airtight plastic bags for chemical analysis. Data on herbage DM yield, grain yield and other agronomic traits were collected and analyzed using GenStat software.

\section{Results and discussion}

\subsection{Varietal Origin/Pedigree and Evaluation}

Bate is the name given by the breeder to a released Oat (Avena sativa L.) variety with the pedigree of ILRI 5453. Bate and the other Oat genotypes were originated from International Livestock research Institute (ILRI) and evaluated against the standard checks (Jasari and Bonsa) at two environments (Bako and Billo) in 2014, 2015 and 2016 main cropping seasons.

\subsection{Herbage dry matter and Grain yield performances}

Based on the analysis of results, two genotypes ILRI 6710 and Bate (ILRI 5453) were beat other accessions in both quantitative and qualitative traits were evaluated. Significant differences $(p \leq 0.01)$ were observed among genotypes in the mean herbage DM yields and grain yields. Bate variety has produced mean herbage DM yields of 8.56 ton $\mathrm{ha}^{-1}$ with $12.93 \%$ ton $\mathrm{ha}^{-1}$ yield advantage over the standard check (Bonsa) which was produced 7.58 ton $\mathrm{ha}^{-1}$. On top of that, as can be seen from the result, Bate (ILRI 5453) shows high herbage yield (DM ton $\mathrm{ha}^{-1}$ ) advantage over the standard check (Bonsa) by $12.93 \%$. Besides, grain yields differed significantly $(\mathrm{p} \leq 0.01)$, which ranged from 28.79 to $31.99 \mathrm{qt} \mathrm{ha}^{-1}$ with a mean of $30.49 \mathrm{qt} \mathrm{ha}^{-1}$. The Bate variety gave the high mean grain yields $\left(31.99 \mathrm{qt} \mathrm{ha}^{-1}\right)$ next to accession 5518 (33.67 qt ha-1) while Jasari variety gave the lowest $\left(28.79 \mathrm{qt} \mathrm{ha}^{-1}\right)$ Table 1.

Table 1: Pooled mean value of herbage yields (DM ton ha ${ }^{-1}$ ) and other parameters of Oat (Avena sativa L.) genotypes across environments from the year 2014-2016 G.C.

\begin{tabular}{|c|c|c|c|c|c|}
\hline Genotypes & PL & $\mathrm{PH}$ & GY & DMY & DMY Yield advantage $\%$ \\
\hline ILRI 6710 & 27.38 & $131.17^{\mathrm{ab}}$ & $31.01^{\mathrm{ab}}$ & $9.03^{\mathrm{a}}$ & 19.13 \\
\hline Bate (ILRI 5453) & 28.13 & $135.03^{\mathrm{a}}$ & $31.99^{\mathrm{ab}}$ & $8.56^{\mathrm{ab}}$ & 12.93 \\
\hline Bonsa (standard check) & 26.12 & $126.33^{\mathrm{bc}}$ & $29.66^{\text {bc }}$ & $7.58^{\mathrm{bc}}$ & - \\
\hline Jasari (local check) & 28.13 & $130.78^{a b}$ & $28.79^{c}$ & $7.69^{b c}$ & 1.45 \\
\hline ILRI 5518 & 27.39 & $132.97^{\mathrm{ab}}$ & $33.67^{\mathrm{a}}$ & $7.36^{\mathrm{c}}$ & -2.90 \\
\hline ILRI 6207 & 27.16 & $131.47^{\mathrm{ab}}$ & $29.06^{\mathrm{bc}}$ & $7.74^{\mathrm{bc}}$ & 2.11 \\
\hline ILRI 712 & 28.20 & $129.58^{\mathrm{b}}$ & $30.07^{\mathrm{abc}}$ & $8.10^{\mathrm{abc}}$ & 6.86 \\
\hline ILRI 8237 & 26.97 & $132.50^{\mathrm{ab}}$ & $29.64^{\mathrm{bc}}$ & $8.21^{\mathrm{abc}}$ & 8.31 \\
\hline Mean & 27.44 & 131.23 & 30.49 & 8.03 & \\
\hline $\mathrm{CV} \%$ & 9.9 & 6.1 & 18.8 & 20.6 & \\
\hline $\operatorname{LSD}(0.05)$ & 1.81 & 5.37 & 3.77 & 1.1 & \\
\hline LS & NS & $*$ & $* *$ & $* *$ & \\
\hline
\end{tabular}

Key: ns =none significant, $* *=$ highly significant, $*=$ significant, $\mathrm{PH}=$ plant height, DMY=dry matter yield, $\mathrm{PL}=$ panicle length, $\mathrm{GY}=$ grain yield, $\mathrm{CV}=$ coefficient of variation, $\mathrm{LS}=$ Level of significance.

\subsection{Nutritional Quality Analysis}

The mean values of nutritional composition of oat (Avena sativa) genotypes tested were presented in table 2 . Significant results $(\mathrm{p}<0.01)$ were observed in nutritive values for DM, IVOMD and OM among the tested genotypes. The highest DM was recorded in genotype ILRI 6710 (61.22\%) which was closely followed by Bate variety $(59.54 \%)$ while ILRI 6207 showed lowest DM content $(52.22 \%)$. 
Table 2: Nutritive value of different accessions of Oat (Avena sativa)

\begin{tabular}{lcccccccc}
\hline \multirow{2}{*}{ Genotypes } & \multirow{2}{*}{ DM\% } & \multicolumn{7}{c}{$\%$ DM } \\
\cline { 3 - 9 } & & Ash & CP & NDF & ADF & ADL & IVOMD & OM \\
\hline ILRI 6710 & 61.22 & 8.26 & 6.81 & 67.19 & 47.42 & 3.65 & 66.03 & 52.96 \\
Bate (ILRI 5453) & 59.54 & 7.80 & 6.43 & 70.03 & 52.78 & 3.37 & 65.00 & 51.74 \\
Bonsa (standard check) & 57.86 & 8.25 & 5.92 & 71.61 & 54.31 & 3.84 & 61.24 & 46.35 \\
Jasari (local check) & 52.89 & 9.19 & 5.41 & 72.32 & 59.16 & 5.12 & 60.39 & 43.70 \\
ILRI 5518 & 53.87 & 9.13 & 5.93 & 70.47 & 61.92 & 5.91 & 61.32 & 44.74 \\
ILRI 6207 & 52.22 & 8.49 & 3.87 & 71.62 & 62.32 & 4.32 & 60.46 & 43.73 \\
ILRI 712 & 54.38 & 9.01 & 5.82 & 72.00 & 60.55 & 6.18 & 59.77 & 45.37 \\
ILRI 8237 & 52.43 & 8.93 & 4.06 & 71.46 & 56.88 & 5.56 & 60.43 & 43.51 \\
\hline Mean & 55.55 & 8.63 & 5.53 & 70.84 & 56.92 & 4.74 & 61.83 & 46.51 \\
CV & 3.0 & 5.4 & 23.8 & 2.9 & 7.6 & 28.8 & 2.0 & 3.4 \\
LSD (0.05) & 3.93 & 1.11 & 3.09 & 4.88 & 10.23 & 3.31 & 2.93 & 3.79 \\
Significance level & $* *$ & $\mathrm{NS}$ & $\mathrm{NS}$ & $\mathrm{NS}$ & $\mathrm{NS}$ & $\mathrm{NS}$ & $* *$ & $* *$ \\
\hline
\end{tabular}

Note: NS, non-significant; **, significant at $\mathrm{p}<0.01$; DM, dry matter; CP, crude protein; NDF, neutral detergent fiber; $\mathrm{ADF}$, acid detergent fiber; IVOMD, in vitro organic matter digestibility; OM, organic matter; $\mathrm{ADL}=\mathrm{Acid}$ detergent lignin $\mathrm{CV}$, coefficient of variation.

Among the tested genotypes, the highest IVOMD was observed in genotype ILRI $6710(66.03 \%)$ followed by Bate variety $(65.00 \%)$. Similarly, Bate variety was showed highest OM content $(51.74 \%)$ next to genotype ILRI 6710 (52.96\%) while Jasari variety showed the lowest IVOMD and OM contents (60.39 and 43.70\%) respectively. Whereas, non-significant results $(\mathrm{p}>0.05)$ were observed among the treatments in Ash, CP, NDF, $\mathrm{ADF}$ and LDF.

\subsection{Stability of Performance/Adaptation}

Yield stability parameters for tested oat genotypes for three years at two locations were studied based on the methods of Eberhart and Russel (1966). Analysis using the GGE biplot confirmed that genotype ILRI 6710 and Bate variety are most stable and desired genotype as compared to the other genotypes since the regression coefficients approximating to unity and had one of the lowest deviations from regression and also have above average mean herbage DM yield. This is implying that it has good general adaptability compared to the remaining tested genotypes in the test environments and similar agro-ecologies (fig.1). Besides, the Bate variety (ILRI 5453) showed herbage yield advantage of about 12.93 over the corresponding check.

Figure1. Showed that stability and adaptability of pigeon pea genotypes across years and locations.

Comparison bipl ot (Total - 83.61\%)

$\frac{1}{0}$

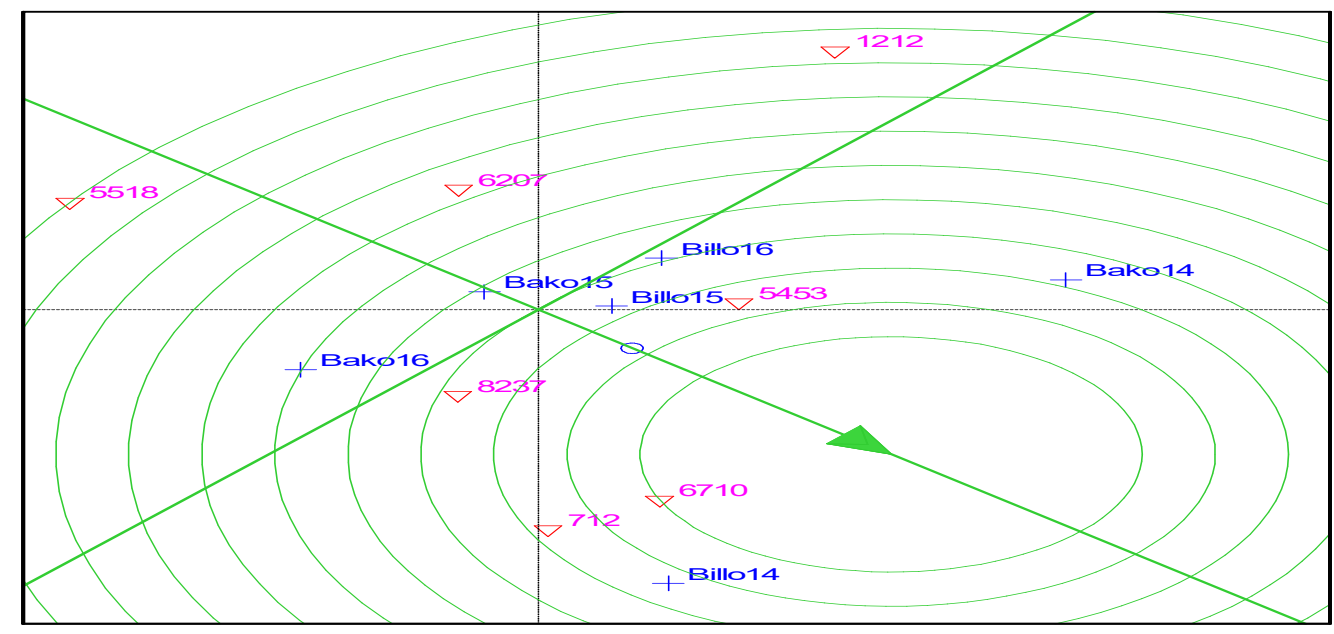

PC2 - 25.76\%

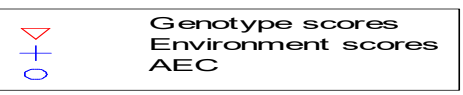




\subsection{Reaction to Major Diseases}

Leaf and steam rest are economically importance disease for cereal production (like fodder oat). In the present study some genotypes (ILRI 5518, Jasari, ILRI 8237 and ILRI 6710) were slightly infected by this disease at few sites. But the rest oat genotypes including Bate variety were free of the stated disease.

\section{Conclusion and Recommendation}

In the present study, though, the genotype ILRI 6710 was found to be top in both quantitative and qualitative traits, unlikely it was rejected to be released and officially registered due to oat rest infection were observed during field evaluation. The released variety, Bate 'ILRI 5453' has better herbage dry matter yield performance, grain yield, good general adaptability and resistant to oat rest as compared to rest genotypes. The released variety also has better nutritional quality, especially dry matter, organic matter and invtro digestibility. Therefore, smallholder farmers and other stockholders who have engaged in animal production can utilize the Bate variety as energy supplements for low quality feed resources.

\section{Acknowledgement}

The authors acknowledge the financial support from the Agricultural growth program (AGP II) of the Oromia Agricultural Research Institute. Bako Agricultural research center for providing logistic support. The authors also express their gratitude to all staff members of the Animal Feed and Range Land management research team of the BARC for the execution of the experiment.

\section{References}

Ahmad, M.A. Jabar, A. Khalique, Saima, F. Shahzad, N. Ahmad, M. Fiaz, U. Younas (2014). Effect of different levels of ndf on voluntary feed intake, dry matter digestibility and nutrients utilization in dry Nili Ravi buffaloes, J. Anim. Pl. Sci., 24 (6) (2014), pp. 1602-1605

Ahmed H, Abule E, Mohammed K, Tredate AC (2010) Livestock feed resources utilization and management as influenced by altitude in central high-lands of Ethiopia. Livest Res Rural Dev 2(12):125-132.

Berhanu G, Adane H, Kahsay B (2009) Feed marketing in Ethiopia: results of rapid market appraisal. Improving productivity and market success (IPMS) of Ethiopian farmers project working paper 15. ILRI (International Livestock Research Institute), Nairobi, Kenya, 64 pp.

CSA (2012) Federal democratic Republic of Ethiopia. Central Statistical Agency. Statistical Abstract (CSA), Addis Ababa, Ethiopia

Eberhart, S.A. and Russell, W.A. 1966. Stability parameters for comparing varieties. Crop Science 6: 36-40.

Rana A.S, Ahmad A.U.H., Saleem N, Nawaz A., Hussian T., Saad M. (2014) Differential response of sorghum cultivars for fodder yield and quality J. Glob. Innov. Agric. Soc. Sci., 2 (1) (2014), pp. 6-10

Zaman, Q., Hussain, M.N., Aziz, A. and Hayat, K. (2006) Performance of High Yielding Oat Cultivars under Agro-Ecological Conditions of D. I. Khan. Journal of Agricultural Research, 44, 29-35. 
Table 3. Agronomic and morphological characteristics of Bate and Jasari varieties.

\begin{tabular}{|c|c|c|}
\hline Characteristics & Bate & Jasari (standard check ) \\
\hline \multicolumn{3}{|l|}{ Adaptation area: } \\
\hline Altitude (masl) & $1500-3000$ & $1500-3000$ \\
\hline Rainfall (mm) & $800-1200$ & $800-1200$ \\
\hline Seeding rate $(\mathrm{kg} / \mathrm{ha})$ : & $70-80 \mathrm{~kg}$ & $70-80 \mathrm{~kg}$ \\
\hline Spacing $\mathrm{b} / \mathrm{n}$ rows $(\mathrm{cm})$ & 25 and drilling & 25 and drilling \\
\hline Planting time: & Mid July & Mid July \\
\hline Fertilizer rate: $(\mathrm{kg} / \mathrm{ha})$ : & $\mathrm{P}_{2} \mathrm{O}_{5}: 46 ; \mathrm{N}: 18$ & $\mathrm{P}_{2} \mathrm{O}_{5}: 46 ; \mathrm{N}: 18$ \\
\hline Days to $50 \%$ flowering: & 89 & 82 \\
\hline Days to seed maturity: & 120 & 115 \\
\hline Height at biomass harvest $(\mathrm{cm})$ : & 135.03 & 130.78 \\
\hline Life span & Annual & Annual \\
\hline Flowering color & White & white \\
\hline Seed color: & White & White \\
\hline Seed size: & Oval & Oval \\
\hline Thousand seed weight (g): & 213 & 188 \\
\hline \multicolumn{3}{|l|}{ Yield } \\
\hline Grain yield(qt ha-1) & 32.99 & 27.79 \\
\hline Biomass yield (DM/t ha ${ }^{-1}$ : & 8.56 & 7.69 \\
\hline \multicolumn{3}{|l|}{ Crop pest reaction (1-9 scale) } \\
\hline B blight & 1 & 2 \\
\hline Yellow rest & 1 & 3 \\
\hline DM (\%): & 59.54 & 52.89 \\
\hline CP (\%): & 6.43 & 5.41 \\
\hline OM (\%): & 51.74 & 43.70 \\
\hline IVOMD (\%): & 65.00 & 60.39 \\
\hline Ash (\%): & 7.80 & 9.19 \\
\hline NDF (\%): & 70.03 & 72.32 \\
\hline $\operatorname{ADF}(\%):$ & 52.78 & 59.16 \\
\hline $\operatorname{ADL}(\%)$ & 3.37 & 5.12 \\
\hline Special merits: & $\begin{array}{l}\text { High biomass } \\
\text { gain }\end{array}$ & \\
\hline Year of release: & 2018 & \\
\hline Breeder/maintainer: & (OARI/ BARC) & \\
\hline
\end{tabular}

Note: $\mathrm{DM}=$ dry matter; $\mathrm{CP}=$ crude protein; $\mathrm{NDF}=$ neutral detergent fiber; $\mathrm{ADF}=$ acid detergent fiber; $\mathrm{IVOMD}=$ in vitro organic matter digestibility; $\mathrm{OM}=$ organic matter, $\mathrm{ADL}=$ Acid detergent lignin, $\mathrm{OARI}=\mathrm{Oromia}$ agricultural research institute, $\mathrm{BARC}=\mathrm{Bako}$ agricultural research center 